\title{
On Object Dialogue Boxes: Silence, Empathy and Unknowing
}

Dr Alexandra Woodall

Head of Learning, Sainsbury Centre for Visual Arts, University of East Anglia ${ }^{1}$ alexandra.woodall@uea.ac.uk

\section{Biography}

Alexandra Woodall is Head of Learning at the Sainsbury Centre for Visual Arts at the University of East Anglia, Norwich, UK, where she also undertakes research and teaches undergraduates and postgraduates across disciplines including Museum Studies, Art History and Education. Her PhD at the School of Museum Studies, University of Leicester, was supervised by Dr Sandra Dudley and explores encounters between people and things, focusing on imaginative and sensory engagements with objects in art galleries. She has worked in museum and gallery learning, interpretation and exhibitions roles in the UK since 2001, including at the Royal Armouries in Leeds, Manchester Art Gallery, Museums Sheffield and Kettle's Yard in Cambridge. She has an MPhil in Mystical Theology from the University of Cambridge and, prior to working in museums and galleries, she was a teacher of Religious Studies and Philosophy.

\section{Dedication}

This paper is written in memory of Dr Elee Kirk (1977 - 2016): a brilliant thinker and doer, a creative museum educator, and an inspiring researcher.

\section{Keywords}

Object Dialogue Box

Mystical theology

Material interpretation

Silence

Unknowing 


\begin{abstract}
Museums and the objects they hold are full of noise, yet at the same time, they are silent. They are 'places of knowledge', where people access and interpret objects through research, dialogue, display and participation. Yet their objects are often hidden away, physically inaccessible, or devoid of original context and information. This paper explores the oxymoronic 'deafening silence' of the museum object by investigating 'Object Dialogue Boxes' and visitors' responses to these. Made by artists Karl Foster and Kimberley Foster, these boxes contain surreal things made as interpretive or pedagogical art objects. Use of these objects, as a form of 'material interpretation' enables visitors to respond to collections in imaginative, empathetic and playful ways. Yet the objects inside the boxes are unfamiliar and strange. Provoking an initial silence, they often destabilise visitors, whose expectations of museum visiting might be to know and find out, but who now find themselves in a situation of deliberate not knowing. This paper explores 'unknowing' as an interpretive strategy, arguing that it allows for rich empathetic responses to objects from visitors. Paradoxically, this engagement is often as much about silence as it is about dialogue. The paper experiments with the twin metaphors of cataphasis and apophasis (derived from mystical theology), to explore some of these paradoxes, and concludes by suggesting they are helpful in developing imaginative strategies for museum and gallery interpretation.
\end{abstract}




\section{Introduction}

In her influential practical guide to making museums more accessible for a wide range of communities, 'museum visionary' Nina Simon² begins her chapter 'Social Objects' with the following:

Imagine looking at an object not for its artistic or historical significance but for its ability to spark conversation. Every museum has artifacts that lend themselves naturally to social experiences. It might be an old stove that triggers visitors to share memories of their grandmother's kitchen, or an interactive building station that encourages people to play cooperatively [...] These artifacts and experiences are all social objects. (Simon 2010, C4)

For Simon, not all objects are social (cf. Appadurai (1986) and Kopytoff (1986)), but those that are, are 'the content around which conversation happens' (2010, C4). Conversation for Simon is a positive outcome of a museum visit, where learning facts about things is not necessarily the central aim, but where an imaginative response to objects, and engagement with both things and with others, is. Those objects that are 'social' have common attributes: they are personal, active, provocative and relational. They inspire dialogue with others.

The objects that Simon describes as being social are arguably those that have the capacity also to engender empathy in museum visitors: they spark conversation, trigger memory or enable cooperation. Although defined in the Oxford English Dictionary (OED) as 'the ability to understand and appreciate another person's feelings, experience etc.', the notion of empathy is a contested one. Discussed variously across disciplines from psychology and the medical humanities (Bleakley 2015) to pedagogy and the teaching of history (Davis et al. 2001), theorists often use the term either epistemologically, to describe empathy as a cognitive attribute, or socially, to describe it as an affective or emotional attribute. In other words, empathy, or understanding another, can either be something learnt as a skill, or it is something that is experienced and felt. And postmodern historians, most notably, Keith Jenkins, debate whether it is even possible to empathise at all (Jenkins 2003). Can we ever step into the shoes of another person? Or is empathy itself a metaphor? For the purposes of 
this paper, a second definition from the OED is also drawn upon, whereby empathy is 'the quality or power of projecting one's personality into or mentally identifying oneself with an object of contemplation, and so fully understanding or appreciating it.' The term 'object' here can thus be understood either as a person (to differentiate it from the subject doing the empathising), or as a physical thing. Both of these are relevant to what follows, although empathy with people through objects is particularly pertinent to museum practice (see Golding \& Modest 2013; Silverman 2010).

This paper is an exploratory one. Focusing on a particular creative and object-based pedagogical practice within the museum or art gallery, I develop Simon's notion that social objects do indeed have the capacity to inspire conversation, dialogue and empathy beyond the factual. While I would argue, going beyond Simon, that all objects have the potential to be social objects, here I have chosen to focus on objects that have been deliberately made to be social, or to be 'dialogic'. But I also suggest that such objects can achieve just the reverse: paradoxically they often inspire silence and an unknowing, which is just as significant. Indeed dialogue and silence are interconnected, working together dialectically. Mirroring the very museum itself, objects both speak and remain silent, and visitors' reactions to them might be at the same time both social (or dialogic) and not social (or silent). In turn, all these reactions can be described as empathetic, be they verbalised or silent.

The paper focuses on responses to objects from Object Dialogue Boxes (although other object-based projects are also included). After a brief methodological overview, I describe what an Object Dialogue Box is, tracing elements of its development, exploring how visitors engage with it, and how museum staff reflect on these engagements. Perhaps unusually, I then introduce the discipline of theology. Drawing on two metaphorical concepts derived from the medieval mystical tradition, and not previously used within museological discourse, cataphasis and apophasis, I discuss what I refer to as 'unknowing' in museums. Use of such theological metaphors seems to open up conversations and offer the potential for understanding object-based museum practices in new ways, not least in providing a new language to theorise the shared conversations, empathy, unknowing and silences provoked by certain objects. Having introduced these concepts, I then return to analyse the conversations inspired by one session using objects from the Object Dialogue Box to suggest that such 
theological language might help us explore some paradoxes of the museum context, and can even be useful in developing interpretation strategies for visitor engagement with objects and with each other.

\section{Methodology}

This paper is derived from fieldwork undertaken between 2013 and 2015 which took a qualitative 'bricoleur' approach (Costley et al. 2010, 90; Denzin and Lincoln 2003, 5), using mixed methods to explore case studies, including reflective interviews, participant observation, and researcher-led workshops. The data used in this paper is predominantly that derived from some of these reflective interviews held at Museums Sheffield, although aspects of one of the researcher-led workshops held for MA students of Public Humanities, are also described and analysed.

Kathryn Roulston uses the term 'reflective interviews' to describe her 'romantic' approach to interviewing: one in which the researcher may contribute ideas and coconstruct data (Roulston 2010). Interviewees here comprised museum staff from across teams (collections, learning and conservation), as well as teachers (mainly senior lecturers at university level) and artists using collections within their practice. They were semi-structured and took place in one-to-one settings (see Denscombe 1998, 113). Each interview began with contextual questions about use of objects and Object Dialogue Boxes and the role the interviewee had in relation to their use with visitors, before moving on to reflections on the value of imaginative interpretations of objects and artwork for both audience and institution.

\section{What is an Object Dialogue Box?}

Object Dialogue Box is the name given to an interpretive resource created by Norwich-based artists Karl Foster and Kimberley Foster during the period when they were working collaboratively under the name 'hedsor' (roughly between 2002 and 2015). ${ }^{3}$ The artists were commissioned on several occasions over a number of years to develop these devices for museums, galleries and heritage sites across the UK, including at the British Library, Royal Norfolk Regimental Museum, Museums 
Sheffield, Manchester Art Gallery, Harewood House, Turner Contemporary, Imperial War Museums, Nantwich Museum and Rochester Cathedral.

I first came across Object Dialogue Boxes in 2004, introduced to them through Bridget McKenzie, then Head of Learning at the British Library, who I interviewed as part of a research project about using galleries to enable children to have philosophical conversations inspired by objects in collections (Woodall 2005). During our discussion, she talked about an extraordinary box that hedsor had made for the Sir John Ritblat Treasures Gallery at the British Library, the permanent exhibition space there, which includes exemplar works, first editions, illuminated manuscripts, and handwritten notebooks. Ranging from Magna Carta, to Gutenberg's 1455 Bible, to Handel's Messiah, to Beatles' lyrics on napkins, all these works are kept behind glass, on display but unable to be read in their entirety: to some extent therefore, they are silenced. A physical book is of course something that usually needs to be held, to turn the pages in order that it can speak. ${ }^{4}$ But here, this opportunity was missing. The Object Dialogue Box was introduced as one way around this silence and lack of tactility. More significantly for the purposes of this paper, the box was developed as a resource for enabling open-ended questioning with no right or wrong answers. Its strange objects provoked visitors to develop narratives and reflect on questions that they themselves posed of items within the collections on display with others in their groups. The ensuing conversations allowed participants to appreciate the stories of others, often responding empathetically. Above all, it allowed them to be comfortable with not knowing (because the objects were deliberately unfamiliar), and to see beyond objects purely as repositories of information.

Consisting of an intriguing outer shell typically designed and constructed as a result of conversations with museum staff, the boxes are often representative of a collection or an institution: they are material metaphors. Manchester Art Gallery's box is a beehive, since bees represent the city's industrial revolutionary heritage (see Figure 1), while that at Turner Contemporary, a gallery without a permanent collection but situated by the sea, is made from a large buoy, many examples of which can easily be seen when gazing out of the vast windows of the building. The box made for the Norwich Regimental Museum was designed as part of an intergenerational project 
between WW2 veterans and secondary school pupils, exploring issues of loss, conflict and memory, and it looks like a giant search-light.

Conversations usually begin almost as soon as visitors see the boxes, especially when sessions are facilitated (as most of them are). The boxes are arguably Simon's 'social objects' par excellence: they are personal, active, provocative and relational, both as containers and in the use of their contents. They encourage talking about objects within a museum, when the voices of these objects might otherwise be silenced. ${ }^{5}$ It is a talking that reveals a distinct form of knowledge, not necessarily based on fact, something that might be called, as will be explored, an 'unknowing'.

Figure 1: Manchester Art Gallery's beehive Object Dialogue Box. Image courtesy Karl Foster and Kimberley Foster.

Object Dialogue Boxes contain a series of surreal objects, usually amalgamations of two familiar things brought together to make something unfamiliar. A toy wheelbarrow pushes along an over-sized apple. A china figure of a cat has its head covered in buttons. The bowl of a spoon is bandaged. An umbrella with its fabric removed has table tennis balls balancing at the end of each spoke. The objects are known and yet they are unknown. They are loud with possibility, yet silent in their impossibility.

Visitors are invited to use the strange things as props, or navigational compasses which allow for playful or empathetic connections to be made between this thing in their hand, and the art gallery or museum's collections on display. Facilitated sessions led by gallery staff or artists encourage reflecting on questions such as: What is it? What does it remind you of? What could it be? Where will it take you? What links will you make? The objects are revealed, selected, questioned and handled to enable the creation of imaginative connections with and between objects in the gallery, and with and between other members of the group.

At Museums Sheffield, for example, one of the extraordinary objects in the hexagonal unravelling wooden box was in fact made from a very ordinary white plate of the sort from which one might eat a school dinner, fastened to the centre of which with string, 
were two smaller white ceramic pieces, one slightly larger than the other (see Figure 2). Both pieces were smooth and almost mushroom-shaped. There was something slightly clinical, perhaps even sinister about this thing. Glassy and cold to the touch, the object had been made heavier than a normal plate by the addition of the 'mushrooms'. When held upside down, the 'mushrooms' dangled, clinking together gently like chimes. Yet when turned back over, the sound of the 'mushrooms' on the plate was a loud, disruptive clattering.

Figure 2: 'Mushrooms on a plate' object from Museums Sheffield's Object Dialogue Box. Image courtesy Karl Foster and Kimberley Foster.

During a research interview, the learning officer there recalled a story created after imaginative handling and exploration of this object, linking it with the collection. In this case, the activity took place in Museums Sheffield's Graves Gallery in 2013. The learning officer describes how after initial reluctance, hesitation and silence, a group of students discovered a painting, Man with a Skull, in the manner of Jusepe de Ribera (see Figure 3), and made up a story:

The man portrayed is a well-loved king, and the plate belonged to him. The king had a servant whom he loved deeply. But the servant became gravely ill and eventually died. The king, having loved the servant, fell into a deep depression, and could not bear to be parted from the servant he had loved. So in order to ensure that he would stay close to his servant, even after death, he decided to cook the body of his servant and then eat him so that he would literally become part of the king. This he did, and all that remained from this gruesome dish were two bones, which the king kept with the plate, and his servant's skull, portrayed in the painting as his very own memento mori. (from interview in Woodall 2016, 238)

Figure 3: Man with a Skull in the manner of Jusepe de Ribera (1590 - 1652). Image courtesy Museums Sheffield. 
This haptic experience of a curious thing is not based on facts, or context, or traditional curatorial knowledge. Perhaps the students did read some label text, and perhaps they did not. This does not matter. The experience does lead to a sort of knowledge though, an experiential knowledge derived through dialogue, imagination, empathy and made-up stories. But it also leads to, and allows for, silences. Sometimes, there are no words. Handling this object, deeply familiar but at the same time deeply unfamiliar, one can make sense of things in a completely unique, and even playful, way. The painting comes alive and is made known and knowable through a relationship with the material object: sometimes the object speaks, the participants speak, the painting speaks.

\section{Objects and dialogue}

There is of course nothing new in using objects in museums as a starting point for conversation. At the British Museum, a whole partnership programme entitled Talking Objects was developed based on the premise that objects talk (Poulter 2010; Hogsden \& Poulter 2012). ${ }^{6}$ Likewise, Collective Conversations at Manchester Museum was a community programme for diverse groups inspired by objects in the stored collections and was established in 2007 as part of the Revealing Histories ${ }^{7}$ work to commemorate the UK Abolition of the Slave Trade Act: objects from nutmeg to a Benin Oba bell 'spoke' to participants and inspired new conversations (see also Lynch \& Alberti 2010). ${ }^{8}$

In their article about Objects Talk, a community-led exhibition held at the Pitt Rivers Museums in 2002-3, McLellan and Douglas note that it is a positive of that museum that objects there are often left to speak for themselves (2004, 57). However, Objects Talk deliberately used community interpretations to "explore the many ways that objects "speak" to people and how people "respond" to them' $(2004,58)$. Often the 'speech' of the objects was about their materiality, texture or weight, and where this was the case, handling objects were placed alongside in the displays created, thereby (and in a way not dissimilar from the Object Dialogue Box) creating a 'visual and tactile interpretation, not as a replacement for curatorial expertise, but as an equivalent to it' $(2004,60)$. 
In some of these projects, it could be argued that the object is employed instrumentally to enable something beyond itself. For example, the object in UCL's The thing is ... project is deliberately staged to stimulate debate, to challenge and to deal with conflict, using Robert Janes' model of museum as 'dialogue centre' (Janes $2009,83)$. It focuses on 'unplanned and incidental' visitor conversations arising from one object. Indeed, project manager Celine West has stated: 'the conversation is the experience' $(2013,109)$. She categorises broad themes of discussions emerging from engaging with objects: narrative/storytelling, questioning, and processing (statements that illustrated visitors' thought processes about things). The object, although 'central', is ironically superseded by conversations of others, and perhaps becomes a mere spectator in the process. Perhaps it is silenced.

Each of the aforementioned programmes has a slightly different objective: all are object-centric, and interestingly all have been devised by learning and outreach teams with aims broadly around access and inclusion, rather than from curatorial perspectives. In projects such as these, objects are often used to find things out, but also to empower, overcome or discuss particular political, social, democratic, wellbeing or equality issues. Objects might even be described as levellers, for everyone can be brought into a conversation about and with an object. Objects can also thereby enable empathy with others.

The very notion of engagement with an object is often described in political terms: the Fosters refer to holding and talking about one of their objects as being about someone 'having ownership over their learning, and that idea of saying you have a voice and we like your voice' (Interview B, 03/05/13 in Woodall 2016, 195). At one museum, sessions led by the learning team for speakers of English as a foreign language always start with objects as the initial basis for conversations, either museum objects or the participants' own things, and likewise, at another institution, a feely-bag is used to 'get the children comfortable about talking about objects'. It is emphasised that 'it's not always about the right and wrong answer; it's about the thinking that you've done to justify what you think' (Interview L, 18/06/13 in Woodall 2016, 195). Things give people voice. As described by one member of staff: 
I would say whether I am using objects or just taking a walk around the gallery, what I am trying to help people do is to develop their own voice, develop confidence in their own opinion, so that they realise that when they see different things on display, that they don't have to take that kind of curatorial or historical point of view all the time, that their opinion is valid. And that all that other information will come once you allow that conversation to take place. (Interview N, 30/07/13 in Woodall 2016, 195-196)

Other officers note confidence in groups derived from handling objects. One recollects a teacher discussing a class, half of which is 'boisterous' and the other half 'mute'. The teacher is amazed at the capacity of one object to affect the class dynamic, stating:

Did you notice when so-and-so was talking about the Qur'an stand? She's really quiet. She doesn't normally speak. And [...] then she'd said something and $[\ldots]$ one of the loud ones, had said something about the artefact and he'd prefaced it by the girl's name [...] And that's a really interesting dynamic because he actually took notice of what she had to say. So not only was she empowered and very confident, other children were then starting to see their peers in a different light. (Interview L, 18/06/13 in Woodall 2016, 196)

Not only might participants or museum visitors feel empathy with one another, but they might also feel empathy with the object itself. ${ }^{9}$ And this empathy might equally render a person speechless (often because the object is so strange and unfathomable), or silent (often because the object is so deafeningly loud), but it might also provoke the opposite of silence: dialogue, conversation, a cacophony of ideas, and an outpouring of thoughts. To explore these contrasting responses to objects, I now turn, perhaps unusually, to explore concepts drawn from medieval theology.

\section{Why draw on theological metaphor?}

Using metaphors from medieval mystical theology to explore these contemporary themes of silence, empathy and dialogue within the museum context requires further explanation, not just for an audience who may not have an academic grounding in 
theology, but also for those for whom recourse to something as potentially alien as theology might seem particularly provocative. Why might it be useful to reflect upon object engagements and silence in the museum through this lens of theological paradox and metaphor?

Some parallels can be drawn between the disciplines of museum studies and theology which, although they have been written about in tandem before (see Wood \& Latham 2011 and 2014), have not, up to this point, been used as one exploratory lens or interdisciplinary dialogue. My aim is to pave the way for research into the practical implications for museums of some of these theological themes, but also to open up discussions in what I call 'theological museology'. In particular, I wish to explore two terms used in medieval mystical theology - cataphasis and apophasis. I draw on contemporary (postmodern) understandings of this mystical language (see Turner 1995; Sells 1994; Nelstrop et al. 2009; Boesel \& Keller 2010) to ask how it might help us (if at all) to explore the many paradoxes inherent in the museum, not least that of silence.

So what is 'mystical theology'? Simplified, the core language of this type of theology is a fusion of two sources: the Hebraic biblical tradition, and classical Greek Platonism (through Plotinus). Mystical theology is a coming together of Moses' encounter with God on Mount Sinai in the Exodus, with Plato's Allegory of the Cave. In the former, God remains hidden in a cloud of unknowability as God says: 'you cannot see my face; for man shall not see me and live' (Exodus 33:20). God remains hidden from humanity. And in the latter, prisoners, bound in a cave since childhood are unable to distinguish between the shadows of reality and reality itself (The Republic Book 7.7). Plato warns that just as 'the eyes may be unsighted in two ways, by a transition either from light to darkness or from darkness to light,' so too it is with the mind. If someone is perplexed, is it because s/he 'has come from a clearer world and is confused by the unaccustomed darkness' or perhaps instead 'dazzled by the stronger light of the clearer world'? $(1987,321)$ Might something similar occur in a museum?

There are some features of mystical texts which I argue have symbiosis with some of the inherent paradoxes of museum processes. Within the mystical texts, common 
metaphors and images are used, which describe the relationship between God (the transcendent, or beyond) and humanity (the immanent, or here and now). Metaphors used to describe the relationship between the immanent and the transcendent, are usually polar opposites of each other: the language used is of absence and presence, knowing and unknowing, ${ }^{10}$ interiority and exteriority, ${ }^{11}$ light and darkness, ${ }^{12}$ ascent and descent ${ }^{13}$, and silence and dialogue. There is a constant dialectic between these poles (and others, for example revelation and concealment, affirmation and denial), always leading to the possible impossibility (and impossible possibility) of oxymoron. Phrases such as 'dazzling darkness' are commonplace. The dialectic pairs are not simply used as a dualistic either/or: it is always both/and and also neither/nor. Both Hebraic and Greek writings have a common dialectical narrative structure:

there is an ascent toward the brilliant light, a light so excessive as to cause pain, distress and darkness: a darkness of knowledge deeper than any which is the darkness of ignorance. The price of the pure contemplation of the light is therefore darkness, even as in Exodus, death, but not the darkness of the absence of light, rather of its excess - therefore a 'luminous darkness' (Turner 1995, 17-18).

Silence and dialogue within a museum could likewise be usefully framed within a similar sort of dialectic. It might be helpful to recognise in museums and galleries a constant similar interplay between poles: rather than understanding an encounter with an object in one way or another, one might understand it through a lens of both/and. ${ }^{14}$

\section{Apophasis and cataphasis}

Accompanying this metaphoric imagery within mystical texts are two Greek terms for describing God (or 'theology' - theo logos): apophasis (or apophatic) and cataphasis (or cataphatic). The apophatic, rather like Jenkins' views on the impossibility of empathy (2003), takes as its starting point that we do not (and cannot) know what sort of a being God is. There is no language to describe what God is. All words fail. God is ineffable, unknowable, and unsayable. Indeed, God is not a being at all. God is not a 'thing' and so is even (a) 'nothing'. But rather than this not knowing being out of 
ignorance, it is an 'acquired ignorance', a 'docta ignorantia'. In fact, theology is understood as a process of 'unknowing', a process of deconstructing what we know. ${ }^{15}$ Also known as the 'via negativa' (negative way), according to Turner, it follows that if God is unknowable, then there is very little that can actually be said about God. Yet apophatic speech is not a case of there simply not being much to say. Rather it is the absolute opposite of this (McIntosh 1998, 124). Or rather 'since most theistic religions actually have a great number of things to say about God, what follows from the unknowability of God is that we can have very little idea of what all these things said of God mean' (Turner 1995, 20). This is to what apophatic theology assents: 'apophatic' being a neologism for 'failure of speech' which 'in face of the unknowability of God, falls infinitely short of the mark' $(1995,20)$. So the phrase 'apophatic theology' is a perfect oxymoron for describing 'that speech about God which is the failure of speech' $(1995,20)$. It is often (mis)associated with many of the negative metaphors: the darkness, the unknowing, the transcendent, mysterious, and silent, and crudely, is often associated with some of the male mystical writers. This term can arguably be a helpful one in describing the 'failures' of knowing objects in a museum, removed as they are from their contexts, sometimes with little provenance, and often hidden from public display.

Yet for all these negatives, as metaphors, and as language, these are still part of the complementary 'cataphatic' tradition, the bright, talkative, verbose, noisy, immanent, fleshy element of theology. The cataphatic is the colourful outpouring of descriptive language: God is good; God is all-knowing; God is all-powerful; God is a father; God is a mother and so on. As Turner explains:

It is the cataphatic in theology which causes its metaphor-ridden character, causes it to borrow vocabularies by analogy from many another discourse, whether of science, literature, art, sex, politics, the law, the economy, family life, warfare, play, teaching, physiology or whatever. It is cataphatic tendencies which account for the sheer heaviness of theological language, its character of being linguistically overburdened... For in its cataphatic mode, theology is, we might say, a kind of verbal riot, an anarchy of discourse in which anything goes. $(1995,20)$ 
So too are objects in museums cataphatic outpourings of 'thingness': there may be an over-abundance of stuff, labels, interpretation and information. To reduce these terms crudely, this type of writing about God is often associated with some of the female mystics, particularly through poems of eros. Yet all language about God is actually cataphatic, even that language which speaks of God using negatives. But theology still comprises a dialectic between the cataphatic and apophatic, the saying and the unsaying, knowing and unknowing, a dialectic which ends in a silence similar to that of the 'verbose teacher, who in shame at having talked too much in the class, lapses into an embarrassed silence' (1995, 23). But both our affirmations (what God is) and also our negations (what God is not) ultimately fail. The route to the apophatic, Turner argues, is thus through the dialectics of the cataphatic. Language is ultimately all we have. But it is not enough.

I now turn to one particular 'mystical' writer, whose use of both cataphatic and apophatic imagery to explore 'unknowing' I argue, might be of particular use in analysing visitor engagements with Object Dialogue Boxes and in turn in developing interpretation strategies.

\section{Unknowing and Object Dialogue Boxes}

In the late fourteenth century, an anonymous English author, probably hailing from somewhere in the East Midlands, wrote The Cloud of Unknowing during a period of mystical revival $(1981,10)$. While this is a theological discourse, or even a meditation on describing attainment of union with God, I argue that some of its content may be of use in reflecting on visitor engagements with bizarre objects within an art gallery. The Cloud author's (neo)Platonic use of the terms 'knowing' and 'unknowing' are cataphatic and apophatic theological metaphors that might help unpick something of what happens during material interpretation using an Object Dialogue Box.

The metaphor of a 'cloud of unknowing' can describe many of the phenomena outlined within this paper, and is a useful way to conceptualise museological processes. I explore this below, through analysis of a workshop session that took place within the Ruskin Collection of the Guild of St George at Museums Sheffield and was facilitated by the author. This eclectic gallery includes paintings, works on 
paper, architectural casts, minerals and other natural objects, amassed by John Ruskin (1819-1900) to inspire the working people, especially those from the city's metalworking industry, by the beauty in natural and architectural things. Based on a session with a small group of MA Public Humanities students from the University of Sheffield, what follows analyses some of the conversations arising, and their resonance with 'unknowing' (see Woodall 2016, 213-226).

[Figure 4 - Unravelling the Object Dialogue Box]

The nature of the session is performative and largely delivered in a theatrical style: there is a long build-up before the box is opened, and initial discussions are directly focused on opening up a space for imagination and wonder. The session begins with the Object Dialogue Box closed and on the floor amongst the students. They are asked a series of open-ended questions: What do you think this is? What do you think might be inside? How do you think it might open? After a brief apophatic silence, cataphatic suggestions begin to emerge:

'It's full of artist's gear - casting and painting materials.'

'It looks like one of those logic puzzles.'

'I can just imagine with the holes in the top, some kind of light emitting from it.'

'It's like something within a tabernacle, like the Ark. It's like Moses going into the mist.'

It is not clear whether the intrigue of the box comes directly from the box itself and the potential of the strange objects within it, whether it comes from the performative ritual of its gradual unveiling (which takes some twenty minutes), or whether it is a mixture of all these interactions (see Dudley 2010; Ting 2010). What is clear is that it provokes wide-ranging discussion. These are cataphatic outpourings about what is still unknown and unknowable - just as in the mystical thick descriptions of God.

Ideas about the contents of the box are then shared readily by members of the group after the box is unravelled (see Figure 4).

'Well, the most obvious thing is it looks like some kind of very uncomfortable work shoe. But obviously no one would be able to put their feet in... Is it 
something to do with weaving? You know, when you use a spinning wheel?

You lace it to the end of your shoe?'

'Maybe it's a shoe converted into something else. It's possibly a nineteenth century shoe.'

'It's about child labour, obviously.'

Stories shared are both based on what is already known, as well as what is guessed, made up, created, imagined, and unknown. Yet when told, the stories are often presented as fact or truth. Students use words such as 'obviously' to describe what it is they are encountering, when such things are by no means obvious. A shoe-like object is 'obviously' something to wear, and something connected with child labour, for example. There is a blurring of what is, and what might be. Things are not 'known' in a common sense: they can be whatever the participants want them to be. There are no right and wrong answers (in contrast with Meszaros 2007).

Through the act of an individual selecting an object to accompany his or her journey around the gallery, a relationship soon develops between student and object chosen, and often with other participants too: 'It was hard to link this to a specific object. I was thinking about Ruskin travelling across Europe. This thing was made to hold papers in. He makes a sketch as he's walking around. It's a useful thing.' Someone else joins in with the dialogue: 'you could put your pencil and paintbrush in. It's like a ready-made art kit all in one.'

The strange object one chooses from within the box encourages different sorts of knowing. For one student, her boat-like object containing a stone led her to Ruskin's mineral cabinet, something she admits she would not usually have found interesting: 'I usually don't appreciate the aesthetic of minerals, but this made me want to know what it was. 'Frustrated by a lack of textual interpretation, she wanted to know more once she has arrived at this display. Another student actually wears his viewfinder and, remarkably through using it, finds a watercolour painted at two different times of day. The gallery text explains this as follows:

\section{North-West Door, Cathedral of Notre Dame, Senlis}

Frank Randal (1852-1917)

watercolour and pencil on paper, 1881 
The lines of this arch don't quite meet in the middle, giving the doorway a lopsided appearance. Randal seems however to have painted each side at different times of day, suggesting he was trying to document the arch more fully by showing the depth carving through shadow on one side, and the colourful stonework on the other.

(Louise Pullen, Ruskin Curator, Museums Sheffield)

The student is able to slide the viewfinder to represent the different light qualities in morning and evening. It is likely that without having the object in his hands, he would not only not have been drawn to observe the collections in such detail, but also that he would not have wanted to learn more about the watercolours which so intrigued him through the viewfinder's lens (see Figure 5).

[Figure 5: Using the viewfinder]

A series of words carved onto individual pieces of wood led another student to find something beautiful in a stained glass window: 'I've got this Robert Filiou quotation: "Art is what makes life more interesting than art." For many artists that may be true. But I don't agree, so I've changed it around to say: "Life is what makes art more interesting than art." And then I learnt about Ruskin: you can't just learn the techniques, you have to have clear perceptions about what moves you. Life experience is how you create the art. I was drawn to this stained glass window: it's beautiful, but what makes it amazing is when light shines through it, so that's another sign of "life making it art". ' A material engagement has inspired not just a detailed material interpretation of displayed objects but it has also elicited a curiosity and a wanting to know more.

As well as traditional forms of knowledge coming from these engagements, so too, some provoke more nonsensical conversations and interpretations. The horn-like object becomes an ashtray for a (painting of a) bird in a tree: 'This horn is a specimen of foreign savagery from a tropical country. But I can't make links with the plughole... It's not an ashtray, is it?' 'It's an ashtray for the bird in the tree? Or you could flat pack the skull of that bird into the plug? '16 
One element that emerged strongly from the session with university students was a concern with the ethical responsibility of a museum or gallery in relation to presentations of 'knowledge' and 'fact'. One student commented: 'You aren't exactly lying to people, but you aren't telling them what it is. You are manipulating them.' Is manipulation in fact what galleries do all the time? Is this what interpretation is? Is the Object Dialogue Box simply making this manifest? Indeed might we not use the box to reflect on the very processes of knowing and interpreting in an art gallery? What are the ethical implications of this sort of interpretive work?

The author of The Cloud of Unknowing speaks too of those 'counterfeit contemplators' who try to know too much, or think they know - a critique which could be railed of many museum professionals and visitors perhaps in their assumption that we can know things that we cannot know, or those who want to name the things in the box that defy naming. In the following extract, the description could perhaps be used of different museum behaviours:

Whoever cares to look at them as they sit at such a time, will see them staring (if their eyes are open) as though they were mad... Some squint as though they were silly sheep that have been banged on the head, and were soon going to die. Some hang their heads on one side as if they had got a worm in their ear. Some squeak when they should speak... Mouth agape, they give the impression that they would hear with their mouths, and not with their ears! $(1981,123-124)$

Unknowing, I argue, could play an important role in making transparent museum interpretation practice. Museums, with their reliance on 'knowledge about things', are doomed to failure because we will never know everything. To use a quotation from Jim Ede, founder of Kettle's Yard in Cambridge:

I often wish that it were possible to look at pictures in something of the spirit with which we would go on a voyage of discovery. On such a journey the explorer would feel that his time had been wasted were he to find nothing strange, nothing new - and yet in art we are annoyed the moment it differs 
from our pre-conceived ideas of what a thing should look like instead of seeing in this difference the possibility of new or renewed vision. (Kettle's Yard 1995)

Interpretive strategies which engage the senses with objects, which use objects to interpret other objects, which, like objects from the Object Dialogue Box, deal in the realms of potentiality, risk, fear, imagination, making up and making, are all about this 'unknowing':

Do not think that because I call it a 'darkness' or a 'cloud' it is the sort of cloud you see in the sky, or the kind of darkness you know at home when the light is out. That kind of darkness or cloud you can picture in your mind's eye in the height of summer, just as in the depth of a winter's night you can picture a clear and shining light. I do not mean this at all. By 'darkness' I mean 'a lack of knowing' - just as anything that you do not know or may have forgotten may be said to be 'dark' to you, for you cannot see it with your inward eye. For this reason it is called 'a cloud', not of the sky, of course, but 'of unknowing', a cloud of unknowing between you and your God. $(1981,66)$

By engaging in sensory and material ways with objects to explore objects and communicate with one another, new potential is opened up in things, and in the way in which galleries interpret, and encourage others to interpret, those things in empathic ways. Being mindful of knowing, but also of the value of unknowing, institutions might open up new strategies for interpreting their collections.

\section{Conclusion: empathy through silence and unknowing}

In her significant and eloquent work on materiality in museums, social anthropologist and museum studies scholar Sandra Dudley, asks:

What might a different, material, even emotional, approach to museum objects contribute to the potential of socially inclusive museums to enable rich, physical and emotional, personal experiences for all their visitors? What would it be like for visitors more often than not to be able not only to read a 
text panel that explains an historical story associated with an object, but also to experience an embodied engagement with that object and thus form their own ideas and/or a tangible, physical connection with those who made it and used it in the past? (Dudley 2010, 4)

In this paper, I have explored how Object Dialogue Boxes offer one way of doing just this: they enable 'rich, physical and emotional, personal experiences'. They can indeed be used as strategies for encouraging empathetic interpretation - both with objects themselves and with fellow visitors. Through deliberate 'unknowing', audiences immediately begin to use their imaginations to make sense of, or 'know', what it is they are looking at. Indeed Karl Foster states: 'if the category of learning that we were engaged in was more readily identified as play, playing with our imaginations, then the process might stimulate less fear' $(2008,123)$. In play there is no need for intellectualising: the immediate, visceral and emotional response to the object is what is important.

There are of course other strategies for an empathetic material interpretation within art galleries that are arguably more commonplace than use of this artist-made box, for helping visitors to engage with paintings and artworks on display within a more traditional framework of knowledge about a thing. Artefacts similar to those in a still life painting might be available for visitors to set up, draw, or engage with creatively as props in the gallery space, ${ }^{17}$ or there might be period clothing for visitors to dress up as though they are characters in particular paintings. ${ }^{18}$ These sorts of interactions encourage an experiential knowing (Storkerson 2009; Sutherland \& Acord 2007) yet it is often a knowing based on fact. As Hilde Hein has stated: 'experiential resonance is not the same as factual confirmation, but it might be a form of affirmation' (2011, 184). Object Dialogue Boxes deliberately encourage (and even manipulate) their users into some sort of 'experiential resonance' or empathy. It is not the sort of empathy that seeks to directly imagine oneself in another's shoes (impossible according to Jenkins (2003)), but it is the sort of empathy by which a visitor's encounter produces understanding through an emotionally engaged imaginative experience.

Dudley argues convincingly that museums need to: 
... return to the material reality of the material, to shift attention back to objects as objects, focusing again on aspects of those things' apparently trivial and obvious material qualities and the possibilities of directly, physically, emotionally engaging with them... $(2012,11)$

While here she is talking about all museum objects, things from the Object Dialogue Box arguably have been created deliberately as pedagogical objects that do exactly this, letting us play to empathise, know and unknow.

It is my contention that if we explore the use of Object Dialogue Boxes in museums through the dialectic of the apophatic and cataphatic we might get some way towards accepting both their own interpretive paradoxes, but also the interpretive paradoxes of all objects in museums. One outcome of this research is thus to encourage the development of strategies for museum interpretation that consciously acknowledge the dialectic between apophatic and cataphatic objects, and are also transparent to visitors in encouraging their thinking about the unknown as well as the known when encountering any objects.

Museums, we might argue, are the epitome of the cataphatic. In them are housed myriad objects. Objects of knowledge, objects of wonder, objects of mystery. The job of the museum is to talk about these objects. It researches them, catalogues them, conserves them, curates them, displays them, interprets them, invites participation in them, knows them. Museums are verbose. They are loud.

Yet also, museums are silent. Many of their objects are hidden away, out of sight, physically inaccessible. They are devoid of their original context, stripped of former meaning and use. And sometimes their objects are entirely unknown, unresearched, unloved, forgotten. Indeed, we might go so far as to say that there is something of the apophatic in all objects in museums, since we can never know everything there is to know about an object. It will always remain, to an extent, silent. Museums and their objects are sites for this constant dialectical interplay between cataphasis and apophasis. And there is something about the pedagogical use of objects within the Object Dialogue Boxes which exemplifies thinking about museums through these 
metaphorical lenses of the apophatic and cataphatic, turning what we might think of and expect to be 'knowing' on its head, to 'surpass understanding'.

Entering the darkness that surpasses understanding, we shall find ourselves brought, not just to brevity of speech, but to perfect silence and unknowing.

Emptied of all knowledge, man is joined in the highest part of himself, not with any created thing, nor with himself, nor with another, but with the one who is altogether unknowable; and in knowing nothing, he knows in a manner that surpasses understanding.

(from Pseudo-Dionysius, The Mystical Theology)

And this has enormous potential for future research on material interpretation, and also for future practice: thinking about objects using these theological metaphors could have impact not only in developing interpretation strategies for visitor engagement with objects, but also for using objects to develop empathy with each other. Museums have a duty to be transparent in their processes: it is important not only that they feel comfortable and confident with unknowing, but also that they actively confront this within their interpretive strategies. To paraphrase Nina Simon's statement about social objects: imagine interpreting an object not through its artistic or historical significance but through its ability to spark both conversation and silence, to spark knowing and unknowing. Imagine the sorts of encounter, and the potential for empathy with people through objects that might emerge.

\section{References:}

Annabel Jackson Associates Ltd. (2013) British Museum Talking Objects Evaluation Summary http://www.annabeljacksonassociates.com/CaseStudies/ET-BritishMuseum.pdf (accessed 25/08/15).

Anonymous (trans. Wolters, C.) (1981) [1961] The Cloud of Unknowing. Middlesex: Penguin.

Appadurai, A. (1986) The Social Life of Things: Commodities in Cultural Perspective. Cambridge: Cambridge University Press. 
Augustine, Saint (trans. R. Pine-Coffin) (1961) Confessions. London: Penguin.

Bleakley, A. (2015) Medical Humanities and Medical Education: How the Medical Humanities can Shape Better Doctors. London: Routledge.

Boesel, C. \& Keller, C. (eds.) (2010) Apophatic Bodies: Negative Theology, Incarnation, and Relationality. New York, Fordham University Press.

Caputo, J. (1997) Deconstruction in a Nutshell: A Conversation with Jacques Derrida. Fordham University Press.

Classen, C. \& Howes, D. (2006) 'The Museum as Sensescape: Western Sensibilities and Indigenous Artifacts' in E. Edwards, C. Gosden \& R. Phillips (eds.) Sensible Objects: Colonialism, Museums and Material Culture. Oxford and New York: Berg, 199-222.

Clifford, J. (1997) Routes: Travel and Translation in the Late Twentieth Century. Cambridge, MA: Harvard University Press.

Costley, C., Elliot, G. \& Gibbs, P. (2010) Doing Work Based Research: Approaches to Enquiry for Insider-Researchers. London: Sage.

Davis, O., Yeager, E. \& Foster, S. (2001) Historical Empathy and Perspective Taking in the Social Studies. New York: Roman \& Littlefield.

Denscombe, M. (1998) The Good Research Guide for Small Scale Social Research Projects. Berkshire: Open University Press.

Denzin, N. \& Lincoln, Y. (2003) Collecting and Interpreting Qualitative Materials. London: Sage.

Dudley, S. (ed.) (2010) Museum Materialities: Objects, Engagements, Interpretations. Oxon: Routledge.

Dudley, S. (2017) 'The power of things: agency and potentiality in the work of historical artefacts' in D. Dean (ed.) A Companion to Public History. London \& New York: John Wiley \& Sons (with kind permission of the author).

Foster, K. (2008) 'A creative project in a primary school: the impact of "bizarre artefacts" in the classroom' in J. Bradley \& M. Rustin (eds.) Work Discussion: Learning from Reflective Practice in Work with Children and Families. London: Karnac Books, 115-134.

Gell, A. (1998) Art and Agency: An Anthropological Theory. Oxford: Oxford University Press.

Golding, V. \& Modest, W. (2013) Museums and Communities: Curators, Collections and Collaboration. London: Bloomsbury Academic. 
Hein, H. (2011) 'The Matter of Museums' in Journal of Museum Education 36.2, 179-188.

Hogsden, C. \& Poulter, E. (2012) 'Contact networks for digital reciprocation' in Museum \& Society 10.2, 81-94.

Janes, R. (2009) Museums in a Troubled World: Renewal, Irrelevance or Collapse? Abingdon: Routledge.

Jenkins, K. (2003) Re-thinking History. London: Routledge.

Kettle's Yard (1995) Open House: Interventions at Kettle's Yard. University of Cambridge: Kettle's Yard.

Kopytoff, I. (1986) 'The Cultural Biography of Things: Commoditisation as Process' in A. Appadurai (ed.) The Social Life of Things: Commodities in Cultural Perspective. Cambridge: Cambridge University Press, 64-91.

Lynch, B. \& Alberti, S. (2010) 'Legacies of prejudice: racism, co-production and radical trust in the museum' in Museum Management and Curatorship Vol. 25, No. 1, $13-35$

Malcolm-Davies, J. (2002) Borrowed Robes: The Educational Value of Costumed Interpretation at Heritage Sites. Unpublished PhD thesis: The University of Surrey. http://www.esade.edu/cedit2003/pdfs/malcomdaviesjm.pdf (accessed 14/09/15).

Meszaros, C. (2007) 'Interpretation and the Hermeneutic Turn' in engage 20: Strategic Interpretation, 17-22.

McIntosh, M. (1998) Mystical Theology: The Integrity of Spirituality and Theology. Oxford: Blackwell.

McLellan, A. \& Douglas, O. (2004) ''Objects Talk': Interpreting objects through community groups' in Journal of Museum Ethnography No. 16, 56-63.

Nelstrop, L. with Magill, K. \& Onishi, B. (2009) Christian Mysticism: An Introduction to Contemporary Theoretical Approaches. Surrey: Ashgate.

Ouzman, S. (2006) 'The Beauty of Letting Go: Fragmentary Museums and Archaeologies of Archive' in E. Edwards, C. Gosden \& R. Phillips (eds.) Sensible Objects: Colonialism, Museums and Material Culture. Oxford and New York: Berg, 269-301.

Plato (1987) [1955] The Republic. (trans. D. Lee) London: Penguin.

Plotinus (1991) The Enneads. (trans. S. MacKenna) London: Penguin.

Poulter, E. (2010) 'Engaging Objects: The Talking Objects Programme at the British Museum' in The International Journal of Arts in Society Volume 4, Issue 5, 341- 350. 
Roulston, K. (2010) Reflective Interviewing: A Guide to Theory and Practice. London: Sage.

Sells, M. (1994) Mystical Languages of Unsaying. Chicago and London: University of Chicago Press.

Silverman, L. (2010) The Social Work of Museums. Oxford: Routledge.

Simon, N. (2010) The Participatory Museum. Santa Cruz: Museum 2.0 http://www.participatorymuseum.org/read/ (accessed 29/08/15).

Storkerson, P. (2009) 'Experiential Knowledge, Knowing and Thinking'. Paper presented at Experiential Knowledge Special Interest Group Conference, London Metropolitan University.

http://experientialknowledge.org.uk/proceedings_speakers_files/Storkerson.pdf (accessed 14/09/15).

Sutherland, I. \& Acord, S. (2007) 'Thinking with art: from situated knowledge to experiential knowing' in Journal of Visual Art Practice 6:2, 125-140.

Ting, W. (2010) 'Dancing pot and pregnant jar? On ceramics, metaphors and creative labels' in S. Dudley (ed.) Museum Materialities: Objects, Engagements, Interpretations. London: Routledge, 189-203.

Turner, D. (1995) The Darkness of God: Negativity in Christian Mysticism. Cambridge: Cambridge University Press.

Vogel, S. (2003) 'Always True to the Object, in our Fashion' in D. Preziosi (ed.) Grasping the World: The Idea of the Museum. Ashgate: Hampshire, 653-662.

West, C. (2013) 'The thing is...: a new model for encouraging diverse opinions in museum outreach' in Museum Management and Curatorship Vol. 28, No. 1, 107-123.

Wood, E. \& Latham, K. (2011) 'The Thickness of Things: Exploring the Curriculum of Museums through Phenomenological Touch' in Journal of Curriculum Theorizing 27: 2, 51-65.

Wood, E. \& Latham, K. (2014) The Objects of Experience: Transforming VisitorObject Encounters in Museums. Walnut Creek, CA: Left Coast Press.

Woodall, A. (2005) Why are we here? An investigation into ways in which museums may be used in the delivery of the Religious Education curriculum, particularly focusing on spiritual and philosophical development in children. Unpublished MA Thesis, University of Leicester.

Woodall, A. (2016) Sensory Engagements with Objects in Art Galleries: Material Interpretation and Theological Metaphor. Unpublished PhD Thesis, University of Leicester. 
${ }^{1}$ Note the research upon which this paper is based was undertaken during the author's PhD in the School of Museum Studies at the University of Leicester (2011-2015), which was funded by the AHRC.

2 This title was ascribed by authors of the Smithsonian Magazine in August 2010:

http://www.smithsonianmag.com/40th-anniversary/nina-simon-museum-visionary-642778/ (accessed 10/08/15).

${ }^{3}$ As of September 2015, the artists have redefined themselves as 'sorhed', 'a gradual evolution of hedsor'. The artists make this explanatory statement on their website:

In our earlier work our objects were exclusively housed as collections in boxes and made in response to specific places or subjects. A colleague coined the name 'Object Dialogue Box' to describe the first box; it remained and for a time defined that element of our practice, as did the name hedsor. Over time our interest has expanded into different contexts. During a period of ten years a gradual change of focus has happened [...] As a result we have ceased to use the term 'Object Dialogue Box' as it limits and defines too much. Similarly, the change in the approach to making objects sees the term 'hedsor' inverted to become 'sorhed' - we have undergone a practice based turn and the name has taken a corresponding turn. http://www.sorhed.com/thinking.html (accessed 14/09/15).

4 Of course, there is now a ubiquity of e-books, which arguably are not physical (although a physical device is needed in order to read) but when this particular project emerged, e-books were not commonplace. ${ }^{5}$ Arguably, all objects in museums are somewhat silenced: they are often violently removed from their original contexts. (See Vogel 2003, 653; Classen \& Howes 2006, 200; Ouzman 2006, 274.)

${ }^{6}$ Funded through the Esmée Fairbairn Foundation, six museums were involved in this programme which explores visitor involvement in the interpretive process through an object-based approach (see Annabel Jackson Associates Ltd 2013)

http://www.britishmuseum.org/about us/community collaborations/partnerships/talking objects.aspx (accessed 14/09/14).

${ }^{7}$ http://www.revealinghistories.org.uk/home.html (accessed 28/08/15).

${ }^{8}$ Much of this work takes its inspiration from the idea of the museum as 'contact zone' as propounded by James Clifford (1997).

${ }_{9}^{9}$ See discussions about the agency and potentiality of objects (Gell 1998; Dudley 2017).

10 Found in The Cloud of Unknowing (Anonymous 1978).

11 Found particularly in Plotinus' Enneads and Augustine's Confessions.

12 In Plato's Allegory of the Cave in The Republic.

13 Deriving from the Exodus account in the Bible.

${ }^{14}$ Indeed to have described crudely at the outset God as 'transcendent' and humanity as 'immanent' is the opposite of how this dialectic works: God is both transcendent and immanent, as is humanity.

15 Use of the term 'deconstruction' here is deliberate: Derrida reflected a great deal on the mystical writers, and there are many similarities between his theories of différance and the apophatic, and these have been widely written about. See for example Caputo 1997.

${ }^{16}$ In another session for primary school children led by an artist-facilitator, the same object is: $A$ blowing thing. A plughole. A buffalo. A rhino. Something for smoking. A bird's beak. A horrible flying creature in a painting. A dinosaur tooth. A velociraptor. The nail of a dinosaur. An elf shoe. Pinocchio's nose holder. An arrow holder for a knight. A sword case. (Woodall 2016, 225)

17 See for example the still life table at York Art Gallery.

18 This is a widespread practice at many galleries (National Portrait Gallery, Walker Art Gallery, Birmingham Museum \& Art Gallery) and other historic sites, especially National Trust properties (see http://www.nationaltrust.org.uk/article-1355814809931/), not to mention the role of costumed interpretation (Malcolm-Davies 2002). 